\title{
NEW EVIDENCE FROM THE EAST POLYNESIAN GATEWAY: SUBSTANTIVE AND METHODOLOGICAL RESULTS FROM AITUTAKI, SOUTHERN COOK ISLANDS
}

\author{
Melinda S Allen \\ Department of Anthropology, University of Auckland, Private Bag 92019, Auckland, New Zealand. Corresponding author. \\ Email: ms.allen@auckland.ac.nz. \\ Rod Wallace \\ Department of Anthropology, University of Auckland, Private Bag 92019, Auckland, New Zealand.
}

\begin{abstract}
East Polynesia was the geographic terminus of prehistoric human expansion across the globe and the southern Cook Islands, the first archipelago west of Samoa, a gateway to this region. Fourteen new radiocarbon dates from one of the oldest human settlements in this archipelago, the Ureia site (AIT-10) on Aitutaki Island, now indicate occupation from cal AD $1225-1430(1 \sigma)$, nearly $300 \mathrm{yr}$ later than previously suggested. Although now among the most securely dated central East Polynesian sites, the new age estimate for Ureia places it outside the settlement period of either the long or short chronology models. The new dates have, however, led to a comfortable fit with the Ureia biological evidence, which suggests not a virgin landscape, but a highly a modified fauna and flora. The results also provide the first systematic demonstration of inbuilt age in tropical Pacific trees, a finding that may explain widely divergent ${ }^{14} \mathrm{C}$ results from several early East Polynesian sites and has implications for the dating of both island colonization and subsequent intra-island dispersals.
\end{abstract}

\section{INTRODUCTION}

Encompassing 22 million $\mathrm{km}^{2}$ of open sea, East Polynesia is a vast region stretching north-south from Hawaii to New Zealand, and west-east from the southern Cook Islands to Rapa Nui; it was the last major region of the world to be permanently settled by human populations. The ancestors of modern East Polynesians managed to find nearly every habitable island; some islands were colonized and then abandoned, others permanently settled (see Kirch 2000). In the process, hundreds of native species went extinct or were extirpated (e.g. Steadman 2006), and entire habitats lost (e.g. Athens 1997). Over time, more than 14 distinct languages developed (R Clark, personal communication, 2006), along with diverse art forms, innovative architecture, and novel material culture. At European contact, vibrant populations with a diversity of complex social, political, and economic systems occupied most land masses of consequence. The time frame of these important cultural processes pivots on when the region was colonized, while identification of their tempo depends on chronometric resolution.

While this grand migration process ended around AD 1300 in New Zealand's Subantarctic Islands (Irwin 1992; Anderson 2005), when it began is uncertain. Those favoring a recent human entry into the region (i.e. a short chronology) rely on direct archaeological evidence (e.g. Spriggs and Anderson 1993; Anderson and Sinoto 2002), while long chronologists accept varied proxies as indicators of human activities, including palynological and sedimentological evidence of marked and sustained disturbance (e.g. Flenley 1993; Kirch and Ellison 1994; Athens 1997). The divide, however, is over more than just the kind of evidence that is considered admissible. Underpinning the short chronology perspective is the idea that early settlers moved rapidly through the region, reaching its furthest outposts so quickly that the process appears to have been nearly instantaneous within the resolution possible by radiocarbon dating, comparable to colonization of islands to the west by Lapita peoples earlier in time (see Kirch 2000). An important difference from a voyaging perspective, however, is the far greater geographic scale of East Polynesia, and the challenge of increasingly smaller island targets (Irwin 1992). The short chronology model also incorporates the idea of an 1800-yr pause between settlement of the western archipelagos of Fiji, Tonga, and Samoa, where colonization is securely dated to around $2900 \mathrm{yr}$ ago (summarized in Kirch 2000). The long chronology model, in turn, rests on the premise that the process of colonization was comparatively slow and sys- 
tematic, with island arcs forming a series of stepping stones, and colonists building cumulative knowledge about the region and its sailing conditions as they moved eastward out of Samoa-Tonga, north to Hawaii, and eventually south to New Zealand (Irwin 1992).

The short chronology model was first formally outlined in concert with a rigorous and systematic appraisal of the East Polynesian ${ }^{14} \mathrm{C}$ database (Spriggs and Anderson 1993). The authors then argued that East Polynesian settlement was probably no earlier than AD 600-950. Recent redating of several presumed settlement sites (e.g. Rolett and Conte 1995; Anderson et al. 1999; Anderson and Sinoto 2002; Conte and Anderson 2003) has led to even more conservative estimates, with Anderson and Sinoto (2002) proposing that "habitation of any kind may not have begun anywhere in the region before AD 900." Most recently, Hunt and Lipo (2006) have proposed a colonization date of about AD 1200 for Rapa Nui, effectively truncating the conventional chronological sequence on that island by $300 \mathrm{yr}$.

In the context of these 2 dichotomous models (see Anderson 1995), the southern Cook Islands play a pivotal role. In terms of distance, they are the closest islands to Samoa, $1400 \mathrm{~km}$ to the west; a direct voyage to the larger Society Islands, bypassing the southern Cooks, would add another $900 \mathrm{~km}$ to the journey. Direct archaeological evidence for human arrival in the southern Cook Islands has been dated to about AD 1000-1200 (Bellwood 1978; Allen 1994; Kirch et al. 1995), with the Ureia site on Aitutaki Island being the most widely accepted early settlement (Spriggs and Anderson 1993). Possible indications of earlier human activity have been found in Mangaia Island pollen cores, where dramatic declines are seen in native forest species, along with sustained increases in charcoal and altered sediment geochemistry (Kirch et al. 1992). Initially, these disturbances were dated to AD 350 and subsequent work at additional sites raised the possibility of anthropogenic influences much earlier in time (Kirch and Ellison 1994). While Anderson (1995) questioned the chronology of the Mangaian pollen sequence, as well as the proposed anthropogenic influences, similar vegetation patterns are seen a few hundred years later at Lake Roto, Atiu Island, at about AD 640 (Parkes 1994, 1997). Parkes further argues that 3 Polynesian introductions appear at this time: sweet potato (Ipomoea batatas), ironwood (Casuarina equisetifolia), and Hibiscus tiliaceus (Parkes 1994, 1997). The identification of Ipomoea batatas pollen might be debated on the grounds that extremely small numbers were obtained (Parkes 1994) and recent studies show that standard extraction techniques tend to destroy the pollen of this particular Ipomoea species (Haberle and Atkin 2005:29). The other 2 taxa, however, were already suspected Polynesian introductions (Fosberg 1975; Franklin and Merlin 1992:8), so their appearance at this time is of considerable interest.

Thus, there is a considerable gap between the direct archaeological evidence for human settlement in the southern Cooks and that from environmental proxies. Herein, we report on 14 new ${ }^{14} \mathrm{C}$ determinations from Ureia (AIT-10), which require a radical revision of the original age estimate for this important early site. These new findings significantly weaken the archaeological foundation of the long chronology model and demonstrate a methodological problem that has the potential to confound our understanding of a number of human dispersal processes, namely inbuilt age in tropical Pacific trees.

\section{DESCRIPTIVE BACKGROUND}

The almost-atoll of Aitutaki consists of a $~ 50-\mathrm{km}^{2}$ triangular-shaped lagoon, flanked on the west by a 16.8 $\mathrm{km}^{2}$ mainland and on the east by a string of small coral islets (Stoddart and Gibbs 1975; Figure 1). The Ureia (AIT-10) site lies on the mainland west coast, on a narrow coastal flat of $<0.5 \mathrm{~km}$ width, which backs up against a steep cliff. Identified as a locus of early settlement some time ago (Bellwood 1978; Allen and Steadman 1990), Allen's $(1992,1994)$ intensive coring and test- 

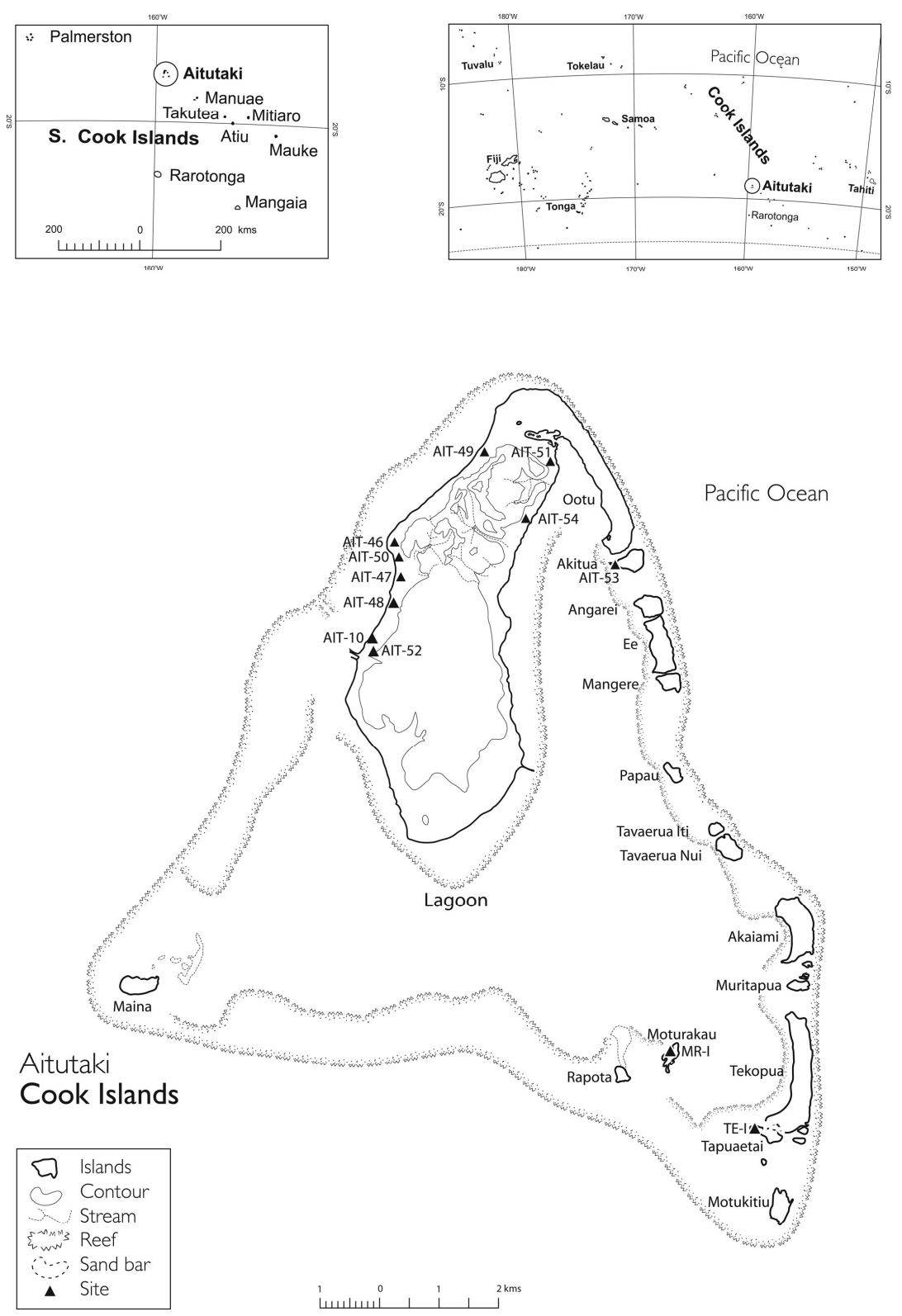

Figure 1 Aitutaki, southern Cook Islands

ing program demonstrated later settlement areas along this coast as well (Figure 1). At Ureia, 3 in situ cultural strata (analytic zones C, E, and G on Figure 2) —evidenced by artifacts, food remains, and in situ hearths, ovens, and postmolds-alternate with storm-deposited sands (analytic zones B, D, F, and H). Below Zone G, cultural materials were identified in a secondary context (Allen 1994), where fine lenses of sterile sand alternating with charcoal-stained sediments and small artifacts indicated fluvial deposition (zones I and J1) (Allen 1998). A small remnant of the apparent source strata for the redeposited cultural remains, designated Zone J2, was also observed in some units. Based on 


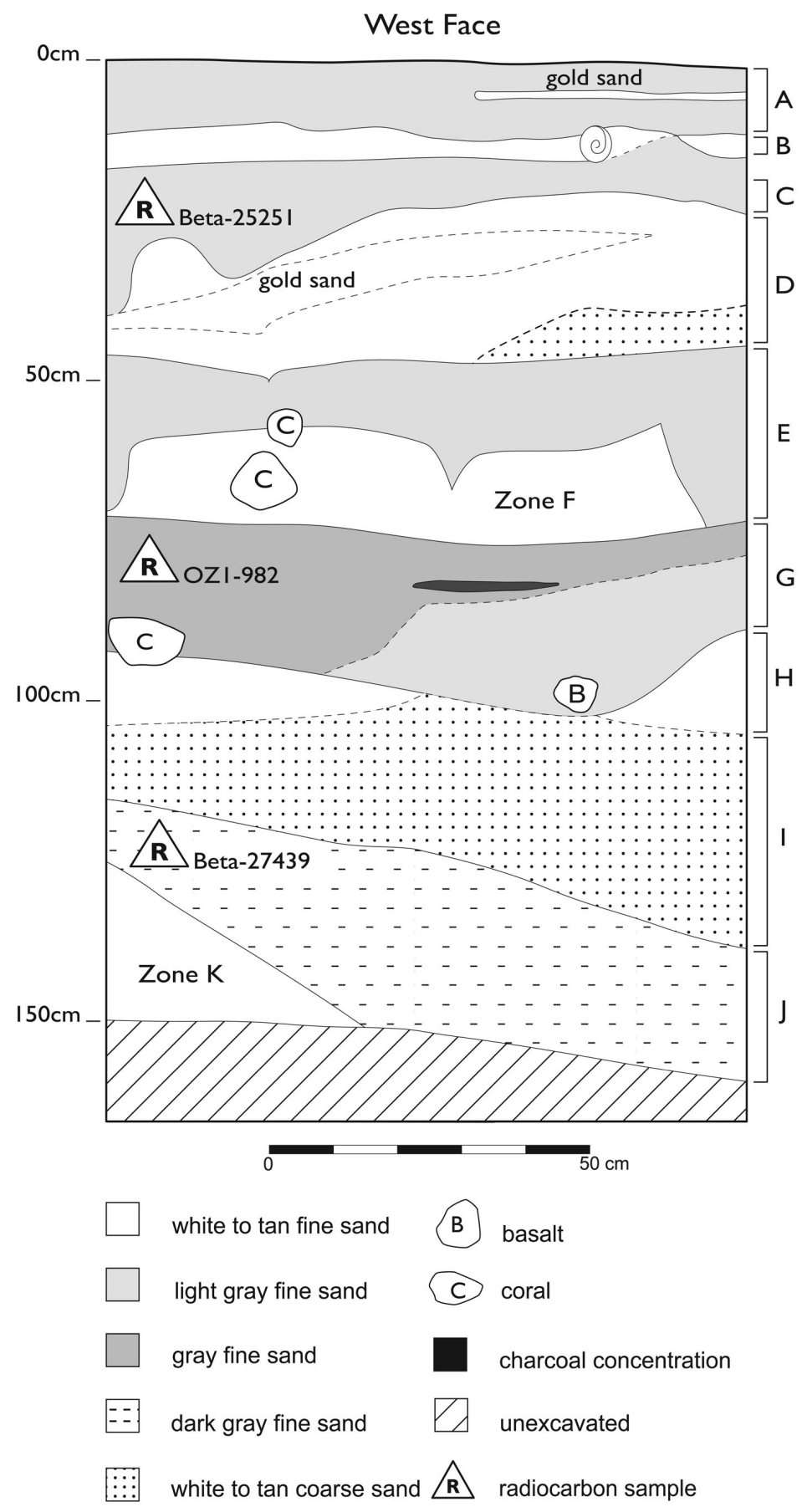

Figure 2 Stratigraphic sequence at the Ureia (AIT-10) site, as seen in west face of TP2

11 prior ${ }^{14} \mathrm{C}$ results (Table 1), the cultural occupation of Zone $\mathrm{G}$ was initially thought to date to the period cal AD 900 to 1040, as originally reported in Bellwood (1978) and Allen and Steadman (1990). 
Attempts to date the basal redeposited cultural remains of Zone $\mathrm{J}$ had been problematic on 3 counts (Allen 1994), 2 clarified by the new results presented herein. Beta-25246 returned an age estimate far too recent relative to other samples in the stratigraphic series, and in hindsight was probably displaced from Zone $\mathrm{C}$ by a large and deep pit or posthole. Beta-40759 and Beta-27439 were also younger than the oldest $2{ }^{14} \mathrm{C}$ determinations of the overlying in situ layer (NZ-1252 and Beta25250), which had been obtained from 2 separate areas, by different excavators, and processed by independent labs. Beta-25247 was of uncertain stratigraphic association, belonging to either Zone G or Zone E, cultural strata that were occasionally not well separated by the intervening sterile storm layer (Zone F). Further, interpretation of Beta-40759, a pearl-shell (Pinctada margaritifera) sample, was hindered by the lack of a locally available $\Delta \mathrm{R}$ value and only a single regional value from the Society Islands.

In 2006, 14 previously collected wood charcoal samples were taxonomically identified and submitted for AMS $(n=13)$ and standard radiometric $(n=1)$ determinations (Table 1), with the objective of refining the age estimate for the redeposited Zone $\mathrm{J}$ cultural materials. Nine samples were taken from zones G, I, and $\mathrm{J}$ of a single excavation unit and another 5 from these same zones in other units with good stratigraphic integrity. Although the original excavation followed natural sedimentary units, thick strata had been divided into 2 or more arbitrary levels. In the case of Zone J, this allowed sampling from several successive levels (levels 12 through 16). All of the 2006 charcoal samples were taxonomically identified and at the time none were considered to be from a particularly longlived species. Coconut (Cocos nucifera) endocarp or nutshell was preferentially selected from zones $\mathrm{I}$ and $\mathbf{J}$ in an effort to date culturally associated remains in the absence of in situ fire features within these strata. Coconut fruits (as opposed to coconut wood) also have the advantage of providing very short-lived materials, as they typically mature within a year. Two samples were split and submitted to separate ${ }^{14} \mathrm{C}$ laboratories for AMS determinations. All results, prior and new, have been recalibrated (see Table 1 for details).

\section{RESULTS}

The new ${ }^{14} \mathrm{C}$ determinations (Table 1) clarify the prior date series and support a rather different age estimate for the initial Ureia occupation. Eight new results from Zone $\mathbf{J}$ date the earliest cultural remains, falling within the period cal AD 1225-1430 (1 $\sigma)$. These carbon samples include both coconut endocarp $(n=6)$ and mixed materials $(n=2)$. Another 6 determinations from Zone $\mathrm{G}$ date to the period cal AD 1220-1440 (1 $\sigma)$, while prior samples from this zone recalibrate to AD 980$1460(1 \sigma)$. Zone E is currently dated to cal AD 1220-1390 (1 $\sigma)$ based on 2 samples reported in Allen (1994), but notably Bellwood's (1978) single sample (NZ-1219) is somewhat later at cal AD 1390-1620 $(1 \sigma)$. Essentially, the ${ }^{14} \mathrm{C}$ age ranges from all 3 cultural strata (zones J, G, and E) are quite similar, overlapping broadly at $1 \sigma$ if the single Bellwood sample from Zone $\mathrm{E}$ is excluded; they suggest a series of occupations on this coastal flat in rapid succession. Further, the combined stratigraphic and chronometric evidence suggests these settlements were repeatedly disrupted by coastal inundations of some magnitude, especially in the case of Zone $\mathbf{J}$ where the cultural stratum was almost completely reworked. The 14th century thus appears to have been a period when the coast was geomorphically unstable and aggradation was rapid; in this respect, our findings are consistent with, and refine, the earlier arguments of Allen (1998). Most generally, regarding the chronology of human settlement in the southern Cook Islands, the cultural sequence of what was the "oldest acceptable dated" archaeological site in this group (Spriggs and Anderson 1993:209) has been truncated by nearly $300 \mathrm{yr}$. 


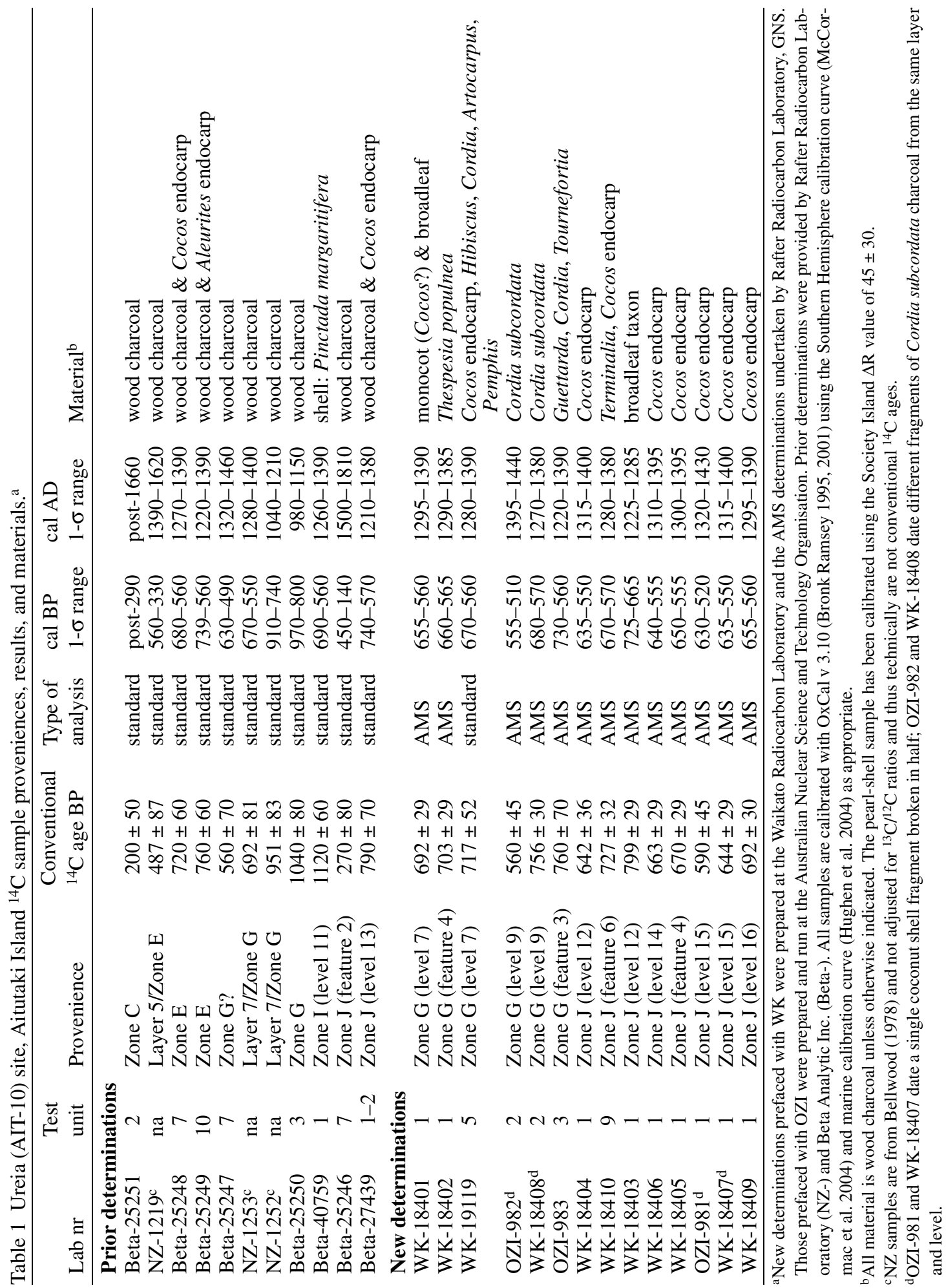


The new results also highlight an important methodological problem. While the determinations from zones $\mathrm{E}$ through $\mathrm{J}$ generally overlap at 1 standard deviation, the ${ }^{14} \mathrm{C}$ ages generally decrease with depth. Consideration of the wood species involved suggests that this stems from inbuilt age, specifically the use of long-lived species with heartwood that significantly predated the burning event. "Old wood" may also be a problem, a reference to taxonomic differences in preservation potential, with species that are more resistant to decay being available for cultural use over longer periods of time (Schiffer 1986). Widely recognized in New Zealand (e.g. McFadgen et al. 1994) and Hawaii, where some tree species can live for several centuries or more, the potential for inbuilt age has been suggested in the tropical central Pacific (e.g. Anderson and Sinoto 2002; Kirch et al. 2004) but not demonstrated.

Comparison of the new Ureia AMS determinations derived from coconut (Cocos nucifera) endocarp $(n=6)$ with those from longer-lived tree species $(n=8)$ shows that the uncalibrated ${ }^{14} \mathrm{C}$ ages for wood samples are, on average, $64{ }^{14} \mathrm{C}$ yr older than those on coconut endocarp, with 1 sample being $149 \mathrm{yr}$ older than the coconut endocarp average. Differences between the 2 group means approach statistical significance (single factor ANOVA, $F$ value $=4.058001, p=0.06)$ and are significant $(F$ value $=118.24743, p=0.001$ ) if OZI-982 is excluded. Notably, all of the samples with ages exceeding $720{ }^{14} \mathrm{C}$ yr derive from indigenous species including Cordia, Guettarda, Tournefortia, and Terminalia and an unidentified broad-leaf (Table 1). Several of these are known to live for decades (Table 2) and Cordia subcordata, which can live for more than a century (see also below), may be especially problematic. There is considerably less variability in the coconut endocarp samples (a very short-lived material). The Thespesia sample (a tree considered to be a Polynesian introduction) also falls within the coconut endocarp age range. Overall, the coconut endocarp and Thespesia samples appear to be the best estimators of the true age of the Zone $\mathrm{J}-\mathrm{H}$ storm event.

The Ureia set of 25 determinations illustrate the advantages of a relatively large ${ }^{14} \mathrm{C}$ assemblage as well. In this example, wood samples with broad age ranges (e.g. OZI-983) and those that might have some degree of inbuilt age (e.g. WK-18403 and WK-18408) can be eliminated from consideration. With a smaller assemblage, as is the case with many East Polynesian sites, and no information on the specific taxa being dated, accurate age estimates would be difficult. The Ureia results suggest that tropical Pacific trees may overestimate the ${ }^{14} \mathrm{C}$ age of a given context by more than a century, and possibly up to 3 centuries if the 2 outlier determinations from Zone G (NZ-1252 and Beta-25250) relate to inbuilt age. To consider this factor further, a curated portion of NZ-1252 was obtained from Rafter Radiocarbon Laboratory in New Zealand. The sample was found to consist entirely of Cordia subcordata.

Also of note are results from 2 sets of samples from the same provenience run by separate labs (Table 1). A fragment of coconut endocarp from Zone J was broken into 2 pieces and 1 each submitted to the Australian Nuclear Science and Technology Organisation (OZI-981) and Rafter Radiocarbon Laboratory via Waikato Radiocarbon Laboratory (WK-18407) for AMS dating. The 1- $\sigma$ ranges are nearly identical. A second paired sample came from the same stratigraphic layer (Zone G) and the same excavation level within that stratum. Two separate wood fragments, both identified as Cordia, were sent to the 2 labs indicated above. In this case, however, the 1- $\sigma$ age ranges do not overlap, with 1 sample (WK-18408) dating to cal AD 1270-1380 and the other (OZI-982) to cal AD 13951440. Given the consistency of results on coconut endocarp, this second set of results may be a further indication of the long-lived nature of Cordia subcordata and its potential for inbuilt age.

Relevant to the foregoing, Cordia subcordata is a common coastal tree in the tropical Pacific. Traditionally, it was used for house posts, canoe paddles, and a variety of other utilitarian objects 
Table 2 Common $^{\mathrm{a}}$ East Polynesian wood charcoal species and estimated life spans ${ }^{\mathrm{b}}$.

\begin{tabular}{|c|c|c|c|}
\hline Taxon & Common name & $\begin{array}{l}\text { Biogeographic status } \\
\text { in Cook Islands }\end{array}$ & $\begin{array}{l}\text { Maximum reported } \\
\text { age }(\mathrm{yr})\end{array}$ \\
\hline Artocarpus altilis & Breadfruit; Kuru & $\begin{array}{l}\text { Polynesian introduction (Fosberg } \\
\text { 1975:76) }\end{array}$ & many decades \\
\hline $\begin{array}{l}\text { Barringtonia } \\
\text { asiatica }\end{array}$ & 'Utu & Indigenous (Fosberg 1975:80) & $80-90$ \\
\hline $\begin{array}{l}\text { Calophyllum } \\
\text { inophyllum }\end{array}$ & Tamanu & $\begin{array}{l}\text { Indigenous (Fosberg 1975:79; } \\
\text { Parkes 1997) }\end{array}$ & many decades \\
\hline Cocos nucifera & Coconut; $N \bar{u}$ & $\begin{array}{l}\text { Indigenous (Parkes 1997:180-1); } \\
\text { probably re-introduced by Poly- } \\
\text { nesians (see Athens 1997:268) }\end{array}$ & up to 100 \\
\hline Cordia subcordata & Tou & Indigenous (Fosberg 1975:81) & $>100$ \\
\hline Guettarda speciosa & ‘Ano & $\begin{array}{l}\text { Indigenous (Fosberg 1975:82; } \\
\text { Kirch and Ellison 1994) }\end{array}$ & not known \\
\hline Hibiscus tiliaceus & Hibiscus; ‘ $A u$ & $\begin{array}{l}\text { Polynesian introduction (Fosberg } \\
\text { 1975:79; Franklin and Merlin } \\
\text { 1992; Parkes 1997:178) }\end{array}$ & several decades \\
\hline Morinda citrifolia & $\begin{array}{l}\text { Indian mulberry; } \\
\text { Nono }\end{array}$ & $\begin{array}{l}\text { Indigenous? (Kirch and Ellison } \\
\text { 1994); Polynesian introduction } \\
\text { (Fosberg 1975:82) }\end{array}$ & $40-50 \mathrm{yr}$ or longer \\
\hline Pandanus tectorius & $\begin{array}{l}\text { Screwpine; } \\
\text { 'Ara-ta`atai }\end{array}$ & $\begin{array}{l}\text { Indigenous (Fosberg 1975; Kirch } \\
\text { and Ellison 1994; Parkes 1997) }\end{array}$ & not known \\
\hline Terminalia glabrata & $\begin{array}{l}\text { Polynesian tropical } \\
\text { almond; Kauariki } \\
\text { enua }\end{array}$ & Indigenous (Fosberg 1975) & up to 100 \\
\hline Thespesia populnea & $\begin{array}{l}\text { Pacific rosewood; } \\
\text { Miro }\end{array}$ & $\begin{array}{l}\text { Polynesian introduction (Fosberg } \\
\text { 1975:79) }\end{array}$ & many decades \\
\hline $\begin{array}{l}\text { Messerschmidia } \\
\text { argentea (syn. } \\
\text { Tournefortia) }\end{array}$ & $\begin{array}{l}\text { Tree heliotrope; } \\
\text { Tau unu }\end{array}$ & Indigenous (Fosberg 1975:81) & several decades \\
\hline
\end{tabular}

(Walter and Sam 2002:150). Perhaps most important in the present context, however, are its widely recognized excellent burning properties, which have led to its "nickname" of "kerosene wood" (Henderson and Hancock 1989; Walter and Sam 2002:150). While little information is available on the life span of Cordia subcordata trees (as is the case with most woody tropical species), Brown (1935:242) reports that Cordia can exceed $10 \mathrm{~m}$ in height and trunks can be more than $250 \mathrm{~cm}$ in diameter. He illustrates an "exceptionally large" specimen with a crown diameter on the order of $15 \mathrm{~m}$ in the Marquesas Islands (Brown 1935: Plate 7C). In the case of Ureia, it is likely that the highenergy storm that destroyed the Zone $\mathrm{J} 2$ settlement also uprooted and destabilized mature coastal trees, potentially including very old individuals. One explanation for our results is that materials of this kind were used for fuel by the Ureia inhabitants during the subsequent Zone G occupation.

\section{DISCUSSION AND CONCLUSIONS}

\section{Implications for Colonization and Settlement of Aitutaki}

Ureia has until now been an archaeological cornerstone in the long chronology model, which originally posited $1600 \mathrm{yr}$ or more of human settlement in the southern Cook Islands (Kirch et al. 1992; Kirch and Ellison 1994). As such, Ureia was important in 3 respects: 1) the previous cal AD 900-1040 (1 $\sigma)$ age estimate for the basal in situ cultural layer placed this occupation near the temporal "boundary" of the short and long chronologies; 2) the redeposited cultural materials of 
Zone $\mathrm{J}$ provided direct evidence of an even earlier human occupation on stratigraphic grounds; and 3 ) the impoverished and anthropogenic biota in the lowest in situ strata suggested that this was not a colonial site, leaving open the possibility of even earlier cultural deposits elsewhere. Ironically, although it is now among the most securely dated central East Polynesian sites, the new age estimate of cal AD 1225-1430 ( 1 б) places it outside the settlement period of either the long or short chronology models.

\begin{tabular}{l} 
Southem Hemisphere Atmospheric data from McComac et al. (2004);OxCal v3.10 Bronk Ramsey (2005); cub r :5; sd :12 prob usp[chron] \\
\hline New Ureia Determinations
\end{tabular}

Figure 3 OxCal multiplot of calibrated age ranges for new ${ }^{14} \mathrm{C}$ samples from the Ureia (AIT-10) site

The new dates do, however, fit comfortably with the Ureia biological evidence, which suggests not a virgin landscape, but a highly a modified fauna and flora. Initial human impact on Polynesian islands was substantial and often swift (e.g. Kirch and Yen 1982; Holdaway and Jacomb 2000). Size reductions, extirpations, and extinctions of native biota, and their replacement by introduced species, are perhaps the most unambiguous and pervasive signatures of human arrival (e.g. Anderson 1995; Steadman et al. 2002; Steadman 2006), at least within a given catchment (see Anderson and Smith 1996; Allen 2004:186-7). In this regard, the faunal remains from the basal zones at Ureia are telling (Table 3). Only 3 of the 18 known native landbirds are represented here and all in small numbers (Steadman 1991; Allen 1992). This pattern stands in sharp contrast to purported colonization sites elsewhere (Steadman 2006). Sea turtle, also typically well represented in early sites (Allen 2007), is also rare at Ureia (Table 3). Human commensals (pig, chicken, dog, and Polynesian rat), in contrast, are present throughout the sequence (Table 3), indicating an agricultural economy was in place and that the Pacific rat (Rattus exulans) was well established. Further, both the wood charcoal 


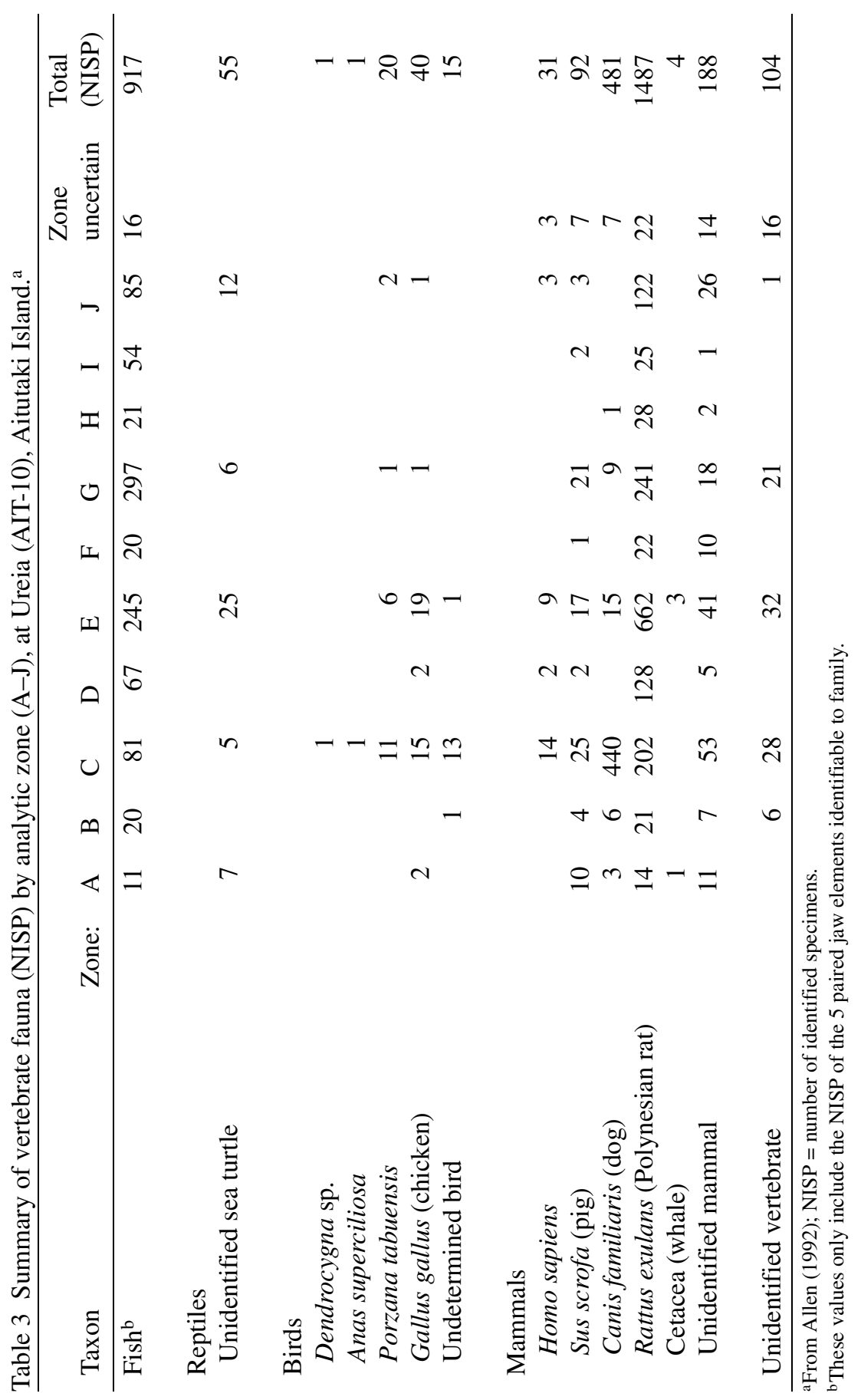


(Table 4) and land-snail assemblages (Allen 1992) point to a human-modified environment. Two food staples, coconut (Cocos nucifera) and breadfruit (Artocarpus altilis), occur in Zone G. These, along with Hibiscus tiliaceus and Thespesia populnea, are considered Polynesian introductions on independent grounds (Fosberg 1975; Franklin and Merlin 1992; Parkes 1997). The lack of native forest species in this assemblage is also notable. Overall, the evidence indicates an anthropogenic landscape with few native species, several Polynesian plant and animal introductions, and an established aboricultural system-evidence that is entirely consistent with the revised age estimates.

Table 4 Ureia (AIT-10) wood charcoal identifications (values $=$ number of identified specimens; $\mathrm{X}=$ present).

\begin{tabular}{|c|c|c|c|c|c|c|c|}
\hline Analytic zone: & $\mathrm{C}$ & $\mathrm{C}$ & $\mathrm{E}$ & $E$ & $\mathrm{E}$ & $\mathrm{G}$ & $\mathrm{J}$ \\
\hline Sample nr: & 1 & 2 & 3 & 4 & 5 & 6 & \\
\hline \multicolumn{8}{|l|}{ Bulk samples ${ }^{\mathrm{a}}$} \\
\hline Aleurites moluccana & & & 4 & 11 & 2 & & \\
\hline Artocarpus altilis & 60 & 4 & & & 9 & 29 & \\
\hline Calophyllum inophyllum & 11 & 126 & & & 21 & & \\
\hline Cocos nucifera (endocarp) & 9 & 9 & 3 & 8 & 25 & & \\
\hline Guettarda speciosa & & & & 1 & 14 & & \\
\hline Hibiscus tiliaceus & & 11 & 7 & 5 & 19 & 32 & \\
\hline Palmae & & 3 & 4 & 7 & 3 & 8 & \\
\hline Pandanus sp. key & & & & & 8 & & \\
\hline cf. Planchonella grayana & & & & & 2 & & \\
\hline Unknown 1 wood & 2 & 1 & 7 & & 3 & 16 & \\
\hline Unknown 2 wood & 13 & 9 & & & & & \\
\hline \multicolumn{8}{|l|}{ Radiocarbon samples ${ }^{\mathrm{b}}$} \\
\hline Artocarpus altilis & & & & & & $\mathrm{X}$ & \\
\hline Cocos nucifera (woody tissue) & & & & & & $\mathrm{X}$ ? & \\
\hline Cocos nucifera (endocarp) & & & & & & $\mathrm{X}$ & \\
\hline Cordia subcordata & & & & & & $\mathrm{X}$ & \\
\hline Guettarda speciosa & & & & & & $\mathrm{X}$ & \\
\hline Hibiscus tiliaceus & & & & & & $\mathrm{X}$ & \\
\hline Pemphis acidula & & & & & & $\mathrm{X}$ & \\
\hline Terminalia sp. & & & & & & & $\mathrm{X}$ \\
\hline Thespesia populnea & & & & & & $X$ & $\mathrm{X}$ \\
\hline Tournefortia argentea & & & & & & $\mathrm{X}$ & \\
\hline
\end{tabular}

aPrevious identifications by G Murakami, International Archaeological Research Institute, Inc., Honolulu (in Allen 1992).

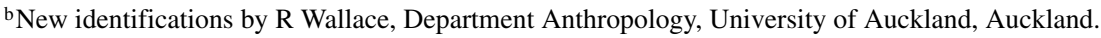

The new results reported here also impact on other findings from the Ureia site. The periodic storm events of the 13th to 14th centuries, as represented in zones J1 to H, Zone F, and Zone D, may have contributed to the site being abandoned for more than a century, with resettlement (Zone C) not resuming until the 17th century AD. Climatic conditions may also have affected Aitutaki's ability to maintain contacts with communities elsewhere, both in the southern Cooks and more distantly. Allen and Johnson's (1997) geochemical study of Aitutaki's stone tool assemblages demonstrated that materials from Zone $\mathrm{G}$ derived from not only local stone sources, but also from quarries in Samoa, the Society Islands, and Mangaia, as well as 7 other unknown but non-local sources. These 
patterns of interaction are now dated to the 13th century $\mathrm{AD}$, somewhat later than previously suggested. By late prehistory (Zone C), in contrast, most of the Ureia lithics were coming from Aitutaki sources, with only 3 non-local ones represented and, in at least 2 cases, the sampled materials may represent little more than re-sharpening of curated adzes (Allen and Johnson 1997:126).

\section{Implications for Cook Island Colonization}

With respect to the timing of Cook Island colonization, 4 other archaeological sites have been considered early (Table 5) but only 2 potentially predate AD 1200: Moturakau Rockshelter (Allen 1992), also on Aitutaki (see Figure 1), and Tangatatau Rockshelter on Mangaia Island (Kirch et al. 1995). Moturakau Rockshelter is dated by 12 samples of which 2, after recalibration, fall in the period cal AD 1160-1290 (1 $\sigma$ ) (Table 5). Only one, however, derives from the basal cultural layer of this rockshelter, where a small hearth was sampled; the other came from higher up in the stratigraphic sequence. The basal layer at Moturakau contains few cultural materials and no diagnostic artifacts or distinctive fauna that support an early age estimate. Problematically, all of the Moturakau ${ }^{14} \mathrm{C}$ samples were wood charcoal and none were identified to species.

Table 5 Recalibrated ${ }^{14} \mathrm{C}$ determinations from other early southern Cook Island sites. ${ }^{\mathrm{a}}$

\begin{tabular}{|c|c|c|c|c|c|}
\hline Lab nr & Provenience & Material & $\begin{array}{l}\text { Conventional } \\
{ }^{14} \mathrm{C} \text { age }\end{array}$ & $\begin{array}{l}\text { cal BP } \\
1-\sigma \text { range }\end{array}$ & $\begin{array}{l}\text { cal AD } \\
1-\sigma \text { range }\end{array}$ \\
\hline \multicolumn{6}{|c|}{ Moturakau, Aitutakib } \\
\hline Beta-44371 & Zone A & charcoal & $230 \pm 50$ & $310-140$ & $1640-1810$ \\
\hline Beta-41572 & Zone B & charcoal & $50 \pm 60$ & 250-modern & $1700-1960$ \\
\hline Beta-44372 & Zone C & charcoal & $180 \pm 50$ & 280-modern & $1670-1960$ \\
\hline Beta-25766 & Zone C & charcoal & $540 \pm 70$ & $630-490$ & $1320-1460$ \\
\hline Beta-42573 & Zone D & charcoal & $390 \pm 50$ & $490-320$ & $1460-1630$ \\
\hline Beta-41573 & Zone D & charcoal & $840 \pm 60$ & $765-670$ & $1185-1280$ \\
\hline Beta-40340 & Zone F & charcoal & $530 \pm 60$ & $555-490$ & $1395-1460$ \\
\hline Beta-40339 & Zone F & charcoal & $640 \pm 60$ & $645-540$ & $1305-1410$ \\
\hline Beta-40341 & Zone $\mathrm{F} / \mathrm{H}$ & charcoal & $670 \pm 60$ & $650-555$ & $1300-1395$ \\
\hline Beta-44373 & Zone $\mathrm{H}$ & charcoal & $560 \pm 70$ & $630-490$ & $1320-1460$ \\
\hline Beta-33445 & Zone $\mathrm{H}$ & charcoal & $670 \pm 60$ & $650-550$ & $1300-1395$ \\
\hline Beta- 25767 & Zone K & charcoal & $840 \pm 80$ & $790-660$ & $1160-1290$ \\
\hline \multicolumn{6}{|c|}{ Tangatatau, Mangaia ${ }^{c}$} \\
\hline Beta-32822 & Zone 15 & charcoal & $330 \pm 80$ & $470-280$ & $1480-1670$ \\
\hline Beta-32830 & Zone 13 & charcoal & $420 \pm 70$ & $510-320$ & $1440-1630$ \\
\hline Beta-32823 & Zone 13 & charcoal & $450 \pm 70$ & $530-320$ & $1420-1630$ \\
\hline Beta-32821 & Zone F3 & charcoal & $200 \pm 60 *$ & 290-modern & 1660-1960* \\
\hline Beta-52937 & Zone 9 & charcoal & $520 \pm 70$ & $560-465$ & $1390-1485$ \\
\hline Beta-52930 & Zone 8 & charcoal & $320 \pm 70$ & $460-280$ & $1490-1670$ \\
\hline Beta-52929 & Zone 8 & charcoal & $480 \pm 60$ & $540-340$ & $1410-1610$ \\
\hline Beta-32824 & Zone 7 & charcoal & $540 \pm 80$ & $630-470$ & $1320-1480$ \\
\hline Beta-32818 & F5 & charcoal & $490 \pm 50 *$ & $540-470$ & $1410-1480 *$ \\
\hline Beta-32825 & F5 & charcoal & $900 \pm 70$ & $900-680$ & $1050-1270$ \\
\hline Beta-32817 & Zone $4 \mathrm{~A}$ & charcoal & $230 \pm 160^{*}$ & 330-modern & $1620-1960 *$ \\
\hline Beta-52932 & F37 & charcoal & $670 \pm 60$ & $650-555$ & $1300-1395$ \\
\hline Beta-52928 & Zone 4B & charcoal & $620 \pm 60$ & $640-530$ & $1310-1420$ \\
\hline Beta-52931 & Zone 2 & charcoal & $560 \pm 60$ & $630-500$ & $1320-1450$ \\
\hline Beta-52936 & Zone 2 & charcoal & $640 \pm 50$ & $640-545$ & 1310-1405 \\
\hline
\end{tabular}


Table 5 Recalibrated ${ }^{14} \mathrm{C}$ determinations from other early southern Cook Island sites. ${ }^{\mathrm{a}}$ (Continued)

\begin{tabular}{llllll}
\hline & & & $\begin{array}{l}\text { Conventional } \\
\text { Lab nr }\end{array}$ & Provenience & Mal BP \\
$1-\sigma$ range & $\begin{array}{l}\text { cal AD } \\
1-\sigma \text { range }\end{array}$ \\
\hline Beta-52938 & Zone 2 & charcoal & $720 \pm 60$ & $680-560$ & $1270-1390$ \\
Beta-52939 & Zone 2 & charcoal & $780 \pm 50$ & $730-650$ & $1220-1300$ \\
Beta-52933 & Zone 2 & charcoal & $930 \pm 80$ & $910-730$ & $1040-1220$ \\
Beta-52934 & Zone 2 & charcoal & $960 \pm 60$ & $910-760$ & $1040-1190$ \\
Beta-32816 & Zone1B & charcoal & $550 \pm 120$ & $650-340$ & $1300-1610$ \\
Beta-52935 & Zone1B & charcoal & $620 \pm 60$ & $640-530$ & $1310-1420$ \\
Beta-32827 & Zone1B & charcoal & $700 \pm 80$ & $670-550$ & $1280-1400$ \\
Beta-32826 & Zone1B & charcoal & $980 \pm 70$ & $930-780$ & $1020-1170$ \\
Anai'o, Ma'uke & & & & & \\
NZ-6958 & Layer 2 & shell & $947 \pm 47$ & $560-465$ & $1390-1485$ \\
NZ-6943 & Layer 4 & shell & $1055 \pm 58$ & $640-530$ & $1310-1420$ \\
NZ-6984 & Layer 4 & shell & $1026 \pm 24$ & $615-535$ & $1335-1415$ \\
NZ-6960 & Layer 4 & shell & $1015 \pm 35$ & $610-520$ & $1340-1430$ \\
NZ-6939 & Layer 4 & shell & $1075 \pm 48$ & $650-550$ & $1300-1400$ \\
Ngati Tiare & & & & & \\
ANU-1154 & Layer 3 & charcoal & $480 \pm 70$ & & \\
NZ-1274 & Layer 3 & charcoal & $667 \pm 73$ & & \\
NZ-1919 & Layer 4 & charcoal & $650 \pm 60$ & & \\
ANU-1155 & Layer 4 & charcoal & $720 \pm 70$ & & \\
\hline
\end{tabular}

${ }^{\text {a Conventional }}{ }^{14} \mathrm{C}$ ages are adjusted for ${ }^{13} \mathrm{C} /{ }^{12} \mathrm{C}$ ratios. Details of calibration are as in Table 1. Asterisk $(*)$ indicates dates that the authors considered later than expected on stratigraphic grounds. All samples are standard radiometric determinations. Samples are listed in stratigraphic order, from most recent to oldest.

${ }^{\mathrm{b}}$ The Moturakau samples, all wood charcoal, are from Allen (1994).

'The Tangatatau samples are from Kirch et al. (1995), with authors noting, "In virtually all cases, the dated material comprised a mixture of wood charcoal, and carbonized Aleurites endocarps and Pandanus drupes."

dAnai'o samples, all Turbo setosus, are from Walter (1998) and calibrated using the single Society Island $\Delta \mathrm{R}$ value of $45 \pm 30$.

${ }^{\mathrm{e}}$ The Ngati Tiare dates are not calibrated as they are not conventional ${ }^{14} \mathrm{C}$ ages, no ${ }^{13} \mathrm{C} /{ }^{12} \mathrm{C}$ ratios are available, and the 2 ANU samples were reported with an old half-life (Bellwood 1978).

The remaining early site of Tangatatau (Steadman and Kirch 1990; Kirch et al. 1992, 1995) is a large overhang shelter in the interior of Mangaia Island with a complex stratigraphic sequence. A robust assemblage of 23 determinations is currently available (Table 5), 4 of which date to the period cal AD 1020-1270 (1 $\sigma)$ (additional dates have been run but are not published; P Kirch, D Steadman, personal communications, 2006). The earliest derives from the basal zone, but problematically, 3 other determinations from this zone are more recent. In contrast to Moturakau, the fauna from the basal Tangatatau strata is consistent with human entry into virgin territory, with numerous extinct or extirpated landbirds represented and few domesticates (Kirch et al. 1995; Steadman 2006). Nevertheless, given the Ureia results and the interior forested location of this site, there is a distinct possibility that the Tangatatau samples may include materials with inbuilt age. Determinations on unambiguous short-lived materials are needed to bolster the extant early Tangatatau determinations.

In light of the foregoing, direct archaeological evidence indicates the likelihood of human populations in the southern Cook Islands at around AD 1000-1200, but on a more tenuous basis than previously supposed. The lack of identified charcoal samples at the 2 key sites leaves open the possi- 
bility of inbuilt age biases and, by extension, colonization at a later point in time. Conversely, however, neither the interior rockshelter of Tangatatau nor the minute offshore islet of Moturakau are likely localities for initial human settlements, and it is logical that other more suitable sites were occupied first. Returning to the palynological evidence, anthropogenic disturbance and the appearance of 2 possible Polynesian introductions on Atiu Island (Parkes 1997) are recalibrated here to AD $610-760\left(1 \sigma ;{ }^{14} \mathrm{C}\right.$ age $1420 \pm 45$, presumably conventional). Recalibration of the original Lake Tiriara core from Mangaia (Kirch et al. 1992) suggests that there is a high probability that sustained forest loss postdates $\mathrm{AD} 420-540\left(68.2 \% ; 1 \sigma\right.$; conventional ${ }^{14} \mathrm{C}$ age $\left.=1640 \pm 50 \mathrm{BP}\right)$ and predates $\mathrm{AD}$ 530-650 (63.1\%; conventional ${ }^{14} \mathrm{C}$ age $\left.=1550 \pm 60 \mathrm{BP}\right)$, pene-contemporaneous with similar changes on Atiu.

In the absence of further field studies, the timing of human arrival in the southern Cook Islands remains open to speculation. Established settlement (sensu Graves and Addison 1995) can be unambiguously placed in the 13th century AD based on the Ureia findings reported herein. One might argue that it is likely to date from the 11th century AD given first the Moturakau and Tangatatau evidence (assuming key samples are not affected by inbuilt age) and second, evidence accumulating from the region at large (e.g. Anderson and Sinoto 2002; Conte and Kirch 2004; Bolt 2005; Hunt and Lipo 2006; Kennett et al. 2006). The available pollen records, in contrast, register similar vegetation trends on 2 islands in the period AD 550-700, and the appearance of at least 2 probable Polynesian introductions. Assuming that the 2 sequences are not unduly affected by old carbon (see Anderson 1995), this evidence may be signalling discovery, visitation, and initial development of small-scale settlements in the southern Cook chain. The sea-level analyses of Dickinson (2003:492, 496-7) may also be relevant here, perhaps partially explaining the temporal gap between the archaeological and palynological records. Dickinson suggests that coastal areas in the Cook-Austral chain were considerably less attractive for human settlers until after AD 800, at which point "declining late Holocene sea level first carried ambient high-tide level below mid-Holocene low-tide level"with implications for coastal stability and inshore marine resources. Sea-level fall may have thus increased island carrying capacities, which, in turn, may have stimulated both the pace of immigration and local population growth, leading to larger, more established, and archaeologically more visible settlements by the 11 th to 12 th centuries AD.

\section{Implications for East Polynesia Colonization and Dispersal}

The implications of our findings for East Polynesia at large are more methodological than substantive. Most importantly, the Ureia analysis calls into question small ${ }^{14} \mathrm{C}$ assemblages. With only 3 determinations for the site as a whole, Bellwood (1978) assigned the lowest in situ occupation to the 11th century AD. A larger assemblage of 9 samples gave Allen and Steadman (1990) a less tidy sequence but one that nevertheless passed the test of "chronometric hygiene" (Spriggs and Anderson 1993). Only with another 2 samples (Allen 1994) did inexplicable inconsistencies begin to emerge. With the inclusion an additional 14 samples, it is now possible to both identify and explain outliers. Several of the latter have been shown to be indigenous trees, with determinations on Cordia subcordata being particularly problematic.

Inbuilt age biases also have relevance for the short chronology model and our understanding of other post-colonization processes. Despite the well-known problems (e.g. Spriggs and Anderson 1993; McFadgen et al. 1994; Anderson 1995), determinations on unidentified materials are commonplace in East Polynesia (but see approach of Kirch et al. 2004), inhibiting objective evaluation of outliers and divergent results. Most problematically, potentially valid early determinations may be dismissed as the result of inbuilt age, providing spurious support to the short chronology model. Further, com- 
parisons of taxonomically identified assemblages with those that are not may suggest contemporaneity where in fact there is none.

Fine-grained chronologies are critical to define the speed, character, and underlying causes of population movements (specific events versus gradual processes), as well as the timing of post-settlement processes such as differentiation in material culture, architecture, languages, etc. Chronometric differences on the order of a century of more, as suggested by comparison of the long- and shortlived species represented at Ureia, are not inconsequential in the context of a regional chronology that could be as brief as $800 \mathrm{yr}$. Inbuilt age and old wood may also skew our understanding of later developments, particularly dispersal of human populations into interior forested areas in conjunction with agricultural expansion, inland settlement, and refuge in response to competition.

\section{CONCLUSIONS}

The corpus of new ${ }^{14} \mathrm{C}$ determinations from the coastal site of Ureia, Aitutaki Island, presents challenges for both the short and long chronology models of East Polynesian settlement and our understanding of the attendant colonizing behaviors (see Anderson 1995). The revised age estimate of about AD 1225-1430 places this site outside (i.e. it is younger than) the settlement period of either model, a finding that is consistent with the associated archaeo-flora and -fauna, but one that weakens the evidential basis for the long chronology model, at least in the southern Cook Islands. At the same time, the demonstration that Cordia subcordata, a common firewood, is most likely a long-lived species (and there may be others) raises questions about the interpretation of unidentified ${ }^{14} \mathrm{C}$ samples from other sites, and their potential to distort our understanding of the process and character of colonization.

Unfortunately, more than a decade on from Spriggs and Anderson's (1993) landmark paper, if we were to limit the East Polynesian ${ }^{14} \mathrm{C}$ database to samples where taxonomic identity was known, and inbuilt age biases could be discounted with certainty, it would be uncomfortably small. Does the East Polynesian record represent a very large pulse of colonists out of West Polynesia, with rapid dispersal on an unprecedented geographic scale to the region's furthest margins? Or have dynamic shorelines in key localities (e.g. southern Cooks and Society Islands), low visibility aceramic occupation records, and insufficient field studies "obscured" earlier signatures of human arrival and a more gradual process of exploration and colonization? In discerning between these 2 contrastive models, it is critical that the potential biases of inbuilt age neither be overlooked when present nor assumed when lacking. Without taxonomic identifications, samples that potentially provide valid support for the long chronology can easily be dismissed as being "too old" based on an assumption of inbuilt age, when in fact they are not. Similarly, unidentified samples from the East Polynesian margins may suggest settlement contemporaneous with that of central archipelagos (and a blitzkrieg-like settlement process), when in fact they suffer from undetected inbuilt age effects.

On a more practical level, our findings provide further support for previous recommendations to: 1) identify all ${ }^{14} \mathrm{C}$ samples as to taxon; and 2) to preferentially date demonstrably short-lived materials such as coconut, Canarium, and Aleurites nutshells, Pandanus drupes, or branch wood. Further, if only trunk or indeterminate wood charcoal is available, Polynesian introductions should be favored over indigenous forest species, as they are less likely to include exceptionally old individuals and at least the possibility that they predate human arrival can be discounted. Finally, with respect to field collecting strategies, we note that large bulk samples not only increase the possibility of recovering short-lived species, but also provide a better basis for making accurate taxonomic determinations on any given charcoal fragment, which can be particularly important for AMS dating. 


\section{ACKNOWLEDGMENTS}

The new analyses were funded by grants from University of Auckland Research Committee and Australian Institute of Nuclear Sciences and Engineering to M Allen. G Murakami (International Archaeological Institute Inc.) provided the early wood charcoal identifications, C Christensen the land-snail determinations. We thank F Petchey and R Green for helpful discussions and A Anderson, P Kirch, and D Steadman for critical readings of the manuscript. The New Zealand Institute of Geological and Nuclear Sciences staff graciously provided an un-analyzed portion of NZ-1252 for identification. P Quinn produced Figures 1 and 2, and refined the OxCal output for Figure 3.

\section{REFERENCES}

Allen MS. 1992. Dynamic landscapes and human subsistence: archaeological investigations on Aitutaki Island, southern Cook Islands [PhD dissertation]. Seattle: University of Washington.

Allen MS. 1994. The chronology of coastal morphogenesis and human settlement on Aitutaki, southern Cook Islands, Polynesia. Radiocarbon 36(1):59-71.

Allen MS. 1998. Holocene sea-level change on Aitutaki, Cook Islands: landscape change and human response. Journal of Coastal Research 14(1):10-22.

Allen MS. 2004. Revisiting and revising Marquesan culture history: new archaeological investigations at Anaho Bay, Nuku Hiva Island. Journal of the Polynesian Society 113(2):143-96; 113(3):224-5 (errata).

Allen MS. 2007. Three millennia of human and sea turtle interactions in Remote Oceania. Coral Reefs doi: 10.1007/s00338-007-0234-X.

Allen MS, Johnson KTM. 1997. Tracking ancient patterns of interaction: recent geochemical studies in the southern Cook Islands. In: Weisler MI, editor. Prehis toric Long-Distance Interaction in Oceania: An Interdisciplinary Approach. Auckland: New Zealand Archaeological Society Monograph 21. p 111-33.

Allen MS, Steadman DW. 1990. Excavations at the Ureia site, Aitutaki, southern Cook Islands: preliminary results. Archaeology in Oceania 25:24-37.

Anderson AJ. 1995. Current approaches in East Polynesian colonization research. Journal of the Polynesian Society 104:110-32.

Anderson AJ. 2005. Subpolar settlement in South Polynesia. Antiquity 79(306):791-800.

Anderson AJ, Sinoto Y. 2002. New radiocarbon ages of colonization sites in East Polynesia. Asian Perspectives 41(2):242-7.

Anderson AJ, Smith I. 1996. The transient village in southern New Zealand. World Archaeology 27(3): 359-71

Anderson AJ, Conte E, Clark G, Sinoto Y, Petchey F. 1999. Renewed excavations at Motu Paeao, Maupiti Island, French Polynesia: preliminary results. New Zealand Journal of Archaeology 21:47-66.

Athens SJ. 1997. Hawaiian native lowland vegetation in prehistory. In: Kirch PV, Hunt TL, editors. Historical Ecology in the Pacific Islands. New Haven: Yale Uni- versity Press. p 248-70.

Bellwood P. 1978. Archaeological Research in the Cook Islands. Pacific Anthropological Records 27. Honolulu: Bernice P Bishop Museum. 214 p.

Bolt R. 2005. Peva: the archaeology of a valley on Rurutu, Austral Islands [PhD dissertation]. Honolulu: University of Hawaii.

Bronk Ramsey C. 1995. Radiocarbon calibration and analysis of stratigraphy: the OxCal program. Radiocarbon 37(2):425-30.

Bronk Ramsey C. 2001. Development of the radiocarbon program. Radiocarbon 43(2A):355-63.

Brown FBH. 1935. Flora of Southeastern Polynesia. III. Dicotyledons. Bernice P Bishop Museum Bulletin 130. Honolulu: BP Bishop Museum. 386 p.

Conte E, Anderson A. 2003. Radiocarbon ages for two sites on Ua Huka, Marquesas. Asian Perspectives 42(1):155-60.

Dickinson WR. 2003. Impact of mid-Holocene hydroisostatic highstand in regional sea level on habitability of islands in Pacific Oceania. Journal of Coastal Research 19(3):489-502.

Flenley JR. 1993. The palaeoecology of Easter Island and its ecological disaster. In: Fischer SR, editor. Easter Island Studies: Contributions to the History of Rapanui in Memory of William T. Mulloy. Oxford: Oxbow Books. p 27-45.

Fosberg FR. 1975. Vascular plants of Aitutaki. In: Stoddart DR, Gibbs PE, editors. Almost-Atoll of Aitutaki: Reef Studies in the Cook Islands, South Pacific. Atoll Research Bulletin 190. Washington, DC: Smithsonian Institution. p 73-84.

Franklin J, Merlin M. 1992. Species-environment patterns of forest vegetation on the uplifted reef limestone of Atiu, Mangaia, Ma'uke, and Miti'aro, Cook Islands. Journal of Vegetation Science 3(1):3-14.

Graves MW, Addison DJ. 1995. The Polynesian settlement of the Hawaiian Archipelago: integrating models and methods in archaeological interpretation. World Archaeology 26(3):380-99.

Haberle S, Atkin G. 2005. Needles in a haystack: searching for sweet potato (Ipomoea batatas (L.) Lam.) in the fossil pollen record. In: Ballard C, Brown P, Bourke RM, Harwood T, editors. The Sweet Potato in 
Oceania: A Reappraisal. Ethnology Monographs 19, Oceania Monograph 56. Sydney: University of Sydney. p 25-33.

Henderson CP, Hancock IR. 1989. A Guide to the Useful Plants of the Solomon Islands. Honiara: Ministry of Agriculture and Land Research Department. 465 p.

Holdaway RN, Jacomb C. 2000. Rapid extinction of the moas (Aves: Dinornithiformes): model, test, and implications. Science 287(5461):2250-4.

Hughen KA, Baillie MGL, Bard E, Beck JW, Bertrand CJH, Blackwell PG, Buck CE, Burr GS, Cutler KB, Damon PE, Edwards RL, Fairbanks RG, Friedrich M, Guilderson TP, Kromer B, McCormac G, Manning S, Bronk Ramsey C, Reimer PJ, Reimer RW, Remmele S, Southon JR, Stuiver M, Talamo S, Taylor FW, van der Plicht J, Weyhenmeyer CE. 2004. Marine04 marine radiocarbon age calibration, $0-26 \mathrm{cal} \mathrm{kyr}$ BP. Radiocarbon 46(3): 1059-86.

Hunt TL, Lipo CP. 2006. Late colonization of Easter Island. Science 311(5767):1603-6.

Irwin G. 1992. The Prehistoric Exploration and Colonisation of the Pacific. Cambridge: Cambridge University Press. 248 p.

Kennett D, Anderson A, Prebble M, Southon J. 2006. Prehistoric human impacts on Rapa, French Polynesia. Antiquity 80(308):340-54.

Kirch PV. 2000. On the Roads of the Winds: An Archaeological History of the Pacific Islands Before European Contact. Berkeley: University of California Press. $446 \mathrm{p}$

Kirch PV, Ellison J. 1994. Palaeoenvironmental evidence for human colonization of remote Oceanic islands. Antiquity 68(259):310-21.

Kirch PV, Yen DE. 1982. Tikopia: The Prehistory and Ecology of a Polynesian Outlier. Bernice P Bishop Museum Bulletin 238. Honolulu: BP Bishop Museum. $396 \mathrm{p}$.

Kirch PV, Flenley JR, Steadman DW, Lamont F, Dawson S. 1992. Ancient environmental degradation. National Geographic Research \& Exploration 8(2):166-79.

Kirch PV, Steadman DW, Butler VL, Hather J, Weisler MI. 1995. Prehistory and human ecology in Eastern Polynesia: excavations at Tangatatau Rockshelter, Mangaia. Archaeology in Oceania 30:47-65.

Kirch PV, Coil J, Weisler MI, Conte E, Anderson AJ. 2004. Radiocarbon dating and site chronology. In: Conte E, Kirch PV, editors. Archaeological Investigations in the Mangareva Islands (Gambier Archipelago), French Polynesia. Contribution No. 62, Archaeological Research Facility. Berkeley: University of California. p 94-105.

McCormac FG, Hogg AG, Blackwell PG, Buck CE, Higham TFG, Reimer PJ. 2004. SHCal04 Southern
Hemisphere calibration, 0-11.0 cal kyr BP. Radiocarbon 46(3):1087-92.

McFadgen BG, Knox FB, Cole TRL. 1994. Radiocarbon calibration curve variations and their implications for the interpretation of New Zealand prehistory. Radiocarbon 36(2):221-36.

Parkes A. 1994. Holocene environments and vegetational change on four Polynesian islands [PhD dissertation]. Hull: University of Hull.

Parkes A. 1997. Environmental change and the impact of Polynesian colonization: sedimentary records from central Polynesia. In: Kirch PV, Hunt TL, editors. Historical Ecology in the Pacific Islands. New Haven: Yale University Press. p 166-99.

Rolett BV, Conte E. 1995. Renewed investigation of the Ha'atuatua Dune (Nuku Hiva, Marquesas Islands): a key site in Polynesian prehistory. Journal of the Polynesian Society 104:195-228.

Schiffer MB. 1986. Radiocarbon dating and the "old wood" problem: the case of the Hohokam chronology. Journal of Archaeological Science 13(1):13-30.

Spriggs M, Anderson A. 1993. Late colonization of East Polynesia. Antiquity 67(255):200-17.

Steadman DW. 1991. Extinct and extirpated birds from Aitutaki and Atiu, southern Cook Islands. Pacific Science 45(4):325-47.

Steadman DW. 2006. Extinction and Biogeography of Tropical Pacific Birds. Chicago: University of Chicago Press. 480 p.

Steadman DW, Kirch PV. 1990. Prehistoric extinction of birds on Mangaia, Cook Islands, Polynesia. Proceedings of the National Academy of Sciences (USA) 87(24):9605-9.

Steadman DW, Pregill GK, Burley DV. 2002. Rapid prehistoric extinction of iguanas and birds in Polynesia. Proceedings of the National Academy of Sciences (USA) 99(6):3673-7.

Stoddart DR, Gibbs PE, editors. 1975. Almost-Atoll of Aitutaki: Reef Studies in the Cook Islands, South Pacific. Atoll Research Bulletin 190. Washington, DC: Smithsonian Institution. 158 p.

Traditional Tree Initiative. URL: http://www.agroforestry.net/tti/index.html. Accessed May 2007.

Walter A, Sam C. 2002. Fruits of Oceania [translated by P Ferrar from Fruits d'Océanie]. Canberra: Australian Centre for International Agricultural Research Monograph No. 85.

Walter R. 1998. Anai'o: The Archaeology of a Fourteenth Century Polynesian Community in the Cook Islands. New Zealand Archaeological Association Monograph 22. Auckland: New Zealand Archaeological Association. 